\title{
Study of a solar air conditioning system with ejector
}

\author{
Mokhtar Ghodbane ${ }^{1}$, Boussad Boumeddane ${ }^{1}$, Abderrahmane Khechekhouche ${ }^{2,3}$, Djamel Benmenine ${ }^{4}$ \\ ${ }^{1}$ Mechanical Engineering Department, Faculty of Technology; University of Blida 1, ALGERIA \\ ${ }^{2}$ Faculty of Technology, University of El Oued, ALGERIA \\ ${ }^{3}$ Laboratory of Electro-Mechanic Systems (LASEM), ENIS of Sfax, University of Sfax, TUNISIA \\ ${ }^{4}$ Renewable Energy Department, Kasdi Merbah University of Ouargla, ALGERIA
}

E-mail*: ghodbannemokhtar39@yahoo.com

\begin{abstract}
Air conditioning is one of the indispensable conditions of well-being in human life, so the face of this research to provide this basic necessity in remote areas and in desert places far from power grids. To achieve this goal, solar air conditioning has been adopted, where the compressor was replaced by an ejector, a parabolic trough solar collector coupled with a thermal generator and a small pump; this means that the solar air conditioner does not need a huge amount of electrical energy to operate. This paper is studding the optical and thermal efficiency of the solar collector used as a solar thermal generator, refrigeration subsystem performance $\left(C O P_{e j c}\right)$ and system thermal ratio of the studied air conditioner, where the cooling load is estimated at $18 \mathrm{~kW}$. This work has allowed to acquire very important knowledge about R718 ejector solar air conditioners. Bouzaréah was chosen as the region to conduct this numerical study on June $11^{\text {th }}, 2018$. Regarding performance of the studied air conditioning subsystem $\left(C O P_{\text {eic }}\right)$ is 0.6235. As for the PTC solar reflector subsystem, its mean optical performance is $75.74 \%$ and its mean thermal performance is $65.01 \%$. Regarding the overall performance of the studied air conditioner, its mean value is 0.407 .
\end{abstract}

Keywords: Solar energy; Water (R718); Ejector; System Thermal Ratio (STR).

Received: 03/02/2020 - Accepted: 10/04/2020

\section{Introduction}

The role of renewable energies in industry and in human life is considerable. Solar energy is the most important source of energy and is available in significant quantities in most regions of the globe $[1,2]$. Use of solar thermal energy in sunny countries such as Algeria is an effective way to overcome energy shortages, especially in rural areas where it is sometimes difficult and expensive to provide them with a conventional electricity grid $[1, \underline{3}, 4]$. In addition, Algeria is a country where the solar energy potential received daily on a horizontal surface of $1 \mathrm{~m}^{2}$ is around $5 \mathrm{kWh}$ over most of the national territory, where this lighting must be used in an intelligent and sustainable way to be able to meet the qualitative and quantitative needs of energies such as the production of electricity, heating, air conditioning, etc. $[1,4]$. Therefore, it is important to exploit this natural and cleaner resource in the field of cold production especially in the solar-driven ejector air conditioning system because of its simplicity of design and implementation.
Due to the increasing cost of energy and the reduction of its sources, a solar-driven ejector air conditioning system using low or medium temperature heat rejection or a free solar energy have become in recent years an interesting subject of study [5-7].

Among the machines that are currently used in the field of air conditioning, the a solar-driven ejector air conditioner on the one hand, because of the air conditioning and cooling required in buildings that exist in industrial fields (Oil and gas processing centers, etc.) and the availability of thermal resources either of solar origin in developing countries, or from low-temperature thermal discharges in industrialized countries, and secondly, thermodynamicists encourage the study of refrigeration production systems directly using solar energy [8-13]. The means by which this operation is carried out is the use of ejector refrigeration machines, also called thermodynamic machines with three temperature sources in which the hot source can be powered by the solar energy or by heat discharges, the cold source is produced at the cold source, i.e. the 
evaporator and the residual heat from the condenser transferred to the ambient medium constitutes the third source. The ejector solar air conditioner is a very effective solution in rural areas and in desert industrial complexes because it has simple assembly and it has an acceptable performance [14-16]. For these reasons, this air conditioning technology is more attractive than conventional air conditioners technology because it is less expensive.

In this work, an ejector air conditioner coupled with a water parabolic trough collector was studied at Bouzaréah region in June $11^{\text {th }}, 2018$. The studied air conditioner does not contain a gas compressor which is the main consumer of electricity. In addition, the studied system uses clean, environmentally friendly refrigerant and does not cause any gaseous emissions that threaten the ozone layer.

\section{Ejector air conditioning subsystem}

The operating mode of the studied machine is presented in the form of equations using the thermodynamic laws such as mass and energy conservation and the impulse conservation to determine the system thermal characteristics. The refrigerant R718 plays a key role in improving the performance of the studied system. Fig. 1 represents a longitudinal section of a typical ejector.

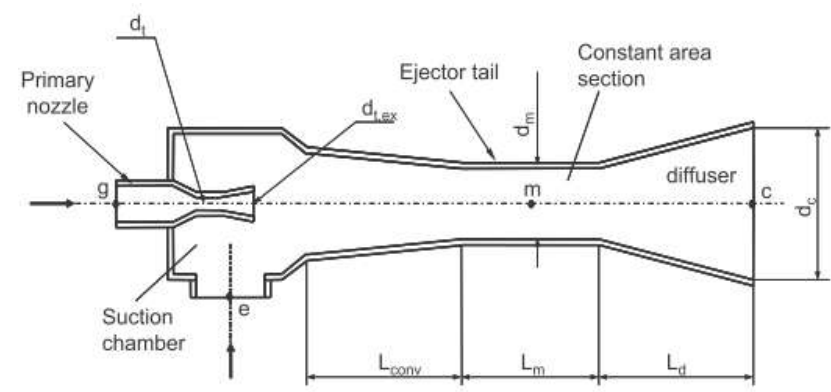

Figure 1. Illustrative schematization of a typical ejector [17].

As shown in Figures 2(a-b), the model of the ejector air conditioner subsystem is based on the refrigerant thermodynamic states in each operating point, as this subsystem has two closed loops [1ㅇ, 19]:

- The driving loop (7-1-2-3-4-5-6-7);

- The refrigerating loops (7-8-9-5-6-7). a) Air conditioning loop

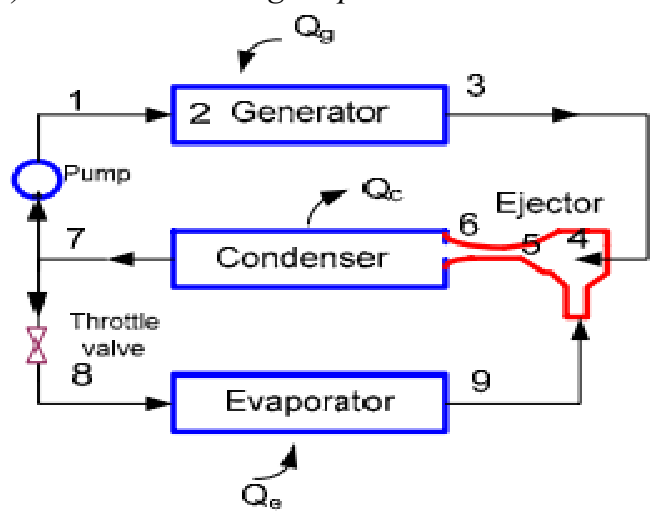

b) (p-h) enthalpy diagram

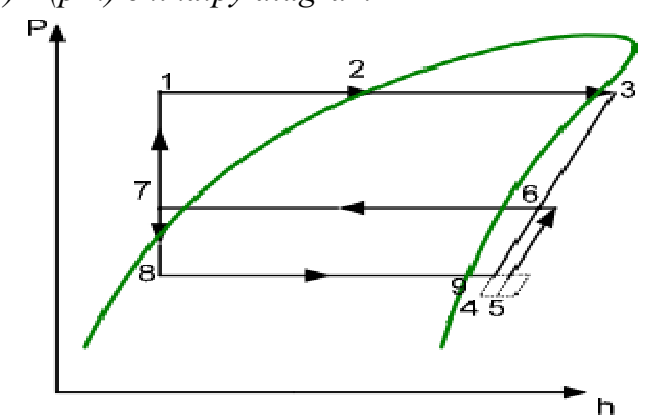

Figure 2. Operating loops of an ejector air conditioner: a) air conditioning loop, b) (p-h) enthalpy diagram.

\section{II.1. Driving loop $(D L)$}

In the driving loop, the energy supplied to the generator is used to evaporate a portion of the refrigerant which represents the driving fluid (primary), which is at high pressure (from state 1 to state 4), then passes through the ejector where it is mixed with the other part of the refrigerant which represents the fluid entrained (secondary), coming from the evaporator and where also performs a pressure recovery (from state 4 to state 6). Then, all of the refrigerant passes through the condenser where it is condensed to the liquid state (from state 6 to state 7). This liquid will be pumped (pressure increase) to the generator and thus completes the cycle (from state 7 to state 1$)$.

\section{II.2. Cooling loop (CL)}

In the refrigeration cycle, part of the refrigerant in the liquid state which represents the entrained fluid (secondary) passes through an expansion valve to bring it to a state of low pressure (from state 7 to state 8 ). The refrigerant subsequently enters the evaporator where it produces by evaporating the desired cold « $18 \mathrm{~kW}$ » (from state 8 to state 9). The refrigerant is mixed with the other part (the driving fluid) in the ejector where it is compressed (from state 9 to state 6) and the mixture 
passes through the condenser where it is condensed to the liquid state and complete thus the cycle (from state 6 to state 7).

These two Loops (DL and CL) illustrate the thermodynamic working principle of the ejector air conditioner.

In order for the ejector conditioning subsystem to work well, the condenser critical condition $\left(\mathrm{P}_{\mathrm{C}}=\right.$ critical pressure) must be achieved. The pressure at the ejector outlet «Diffuser» (P6) is less than or equal to the condenser critical pressure (P6 $\leq \mathrm{PC})$. In this study, a constant pressure mixing ejector (CPM ejector) has been used, as the ejector neck outlet is in the suction chamber before the fixed chamber, the primary and secondary flows are mixed in the chamber aspiration at this pressure. The pressure of the mixing streams remains constant along the chamber from the ejector neck outlet to the inlet of the constant surface section. Therefore, CPM ejector has better efficiency than the rest of the ejector.

For optimal understanding of the ejector working principle, it is advisable to familiarize yourself with the gas-dynamic lessons and a good understanding of the working principle of convergent-divergent pipes [19-22].

According to Figures 2(a-b), the energy balance at the mixing point inside the ejector is given by [19-21] :

$$
\left(\mathrm{m}_{\mathrm{g}}+\mathrm{m}_{\mathrm{e}}\right) \mathrm{h}_{5}=\mathrm{m}_{\mathrm{g}} \cdot \mathrm{h}_{3}+\mathrm{m}_{\mathrm{e}} \cdot \mathrm{h}_{9}
$$

As for the isentropic efficiency of the ejector nozzle, it is given by [19-21] :

$$
\eta_{\mathrm{N}}=\frac{\mathrm{h}_{3}-\mathrm{h}_{4}}{\mathrm{~h}_{3}-\mathrm{h}_{4, \mathrm{is}}}
$$

Regarding diffuser isentropic efficiency, it can be calculated as follow [19-21] :

$$
\eta_{D}=\frac{h_{6, \text { is }}-h_{5}}{h_{6}-h_{5}}
$$

Concerning mass ratio (drive ratio), is given by [18-21]:

$$
\begin{aligned}
& \omega=\frac{\mathrm{m}_{\mathrm{e}}}{\mathrm{m}_{\mathrm{g}}}= \\
& \quad \sqrt{\left(\eta_{\mathrm{N}} \cdot \eta_{\mathrm{D}}\right)\left(\left(\mathrm{h}_{3}-\mathrm{h}_{4, \text { is }}\right) /\left(\mathrm{h}_{6, \text { is }}-\mathrm{h}_{5}\right)\right)}-1
\end{aligned}
$$

As for the isentropic ejector efficiency, it can be calculated by [19-21] :

$$
\lambda=\eta_{\mathrm{N}} \cdot \eta_{\mathrm{D}}
$$

Regarding subsystem compression ratio, it is defined as follow [18-21]:

$$
\mathrm{r}_{\mathrm{p}}=\mathrm{P}_{\mathrm{c}} / \mathrm{P}_{\mathrm{e}}
$$

As for the ejector air conditioning subsystem performance, it is the ratio between the cooling capacity " $\mathrm{Q}_{\mathrm{e}},(\mathrm{W})$ " and the required heat input " $\mathrm{Q}_{\mathrm{g}},(\mathrm{W})$ " to the ejector $[\underline{18-21,} \underline{23}]$ :

$$
C O P_{e j c}=\frac{Q_{e}}{Q_{g}}=\frac{m_{e}\left(h_{9}-h_{8}\right)}{m_{g}\left(h_{3}-h_{1}\right)}
$$

Where " $\mathrm{h}(\mathrm{J} / \mathrm{kg})$ " refers to the Enthalpy, " $\mathrm{m}_{\mathrm{g}},(\mathrm{kg} / \mathrm{s})$ " is the R718 mass flow rate into the generator and " $\mathrm{m}_{\mathrm{e}}$, $(\mathrm{kg} / \mathrm{s})$ " is the R718 mass flow rate into the evaporator.

The thermodynamic analysis of ejector air conditioning subsystem loops was carried out with the Engineering Equation Solver (EES).

\section{Solar collector subsystem}

The family of linear solar concentrators includes two types, the first is the linear Fresnel reflectors (LFRs) [24-27] and the second is the parabolic trough collectors (PTCs) [28-30]. The operating principle of a parabolic trough collectors (PTC) lies in its parabolic mirror in the form of a half cylinder, where this mirror can be rotated following the path of the sun to constantly redirect and focus the beam radiation "DNI, $\left(\mathrm{W} / \mathrm{m}^{2}\right)$ " towards an receiver tube where the working fluid passes to gain heat.

One of the most important objectives of this part of the study is to determine the change in heat loss coefficient " $\mathrm{U}_{\mathrm{L}},\left(\mathrm{W} / \mathrm{m}^{2} . \mathrm{K}\right)$ " that helps to determine the heat loss amount around the studied solar reflector. Table 1 and Table 2 show the geometric and optical parameters of the studied PTC.

Table 1 . PTC geometric parameters

\begin{tabular}{|c|c|}
\hline Geometric characteristics & Value (mm) \\
\hline Outside diameter of the absorber (Do) & 22 \\
\hline Inner diameter of the absorber $(\mathrm{Di})$ & 20 \\
\hline Outer diameter of the window $\left(\mathrm{D}_{\mathrm{G}, \mathrm{o}}\right)$ & 26 \\
\hline Inside diameter of the glass $\left(\mathrm{D}_{\mathrm{G}, \mathrm{i}}\right)$ & 23.5 \\
\hline Mirror length $(\mathrm{L})$ & 12270 \\
\hline Mirror width $(\mathrm{l})$ & 1200 \\
\hline
\end{tabular}

The studied system is installed in the North Algeria, exactly in the research center of Bouzaréah in the geometrical coordinates are $36^{\circ} 47^{\prime} 24$ "North, $3^{\circ} 01^{\text {' }}$ 04" East, its altitude is $230 \mathrm{~m}$ and its surface is $22 \mathrm{~km}^{2}$. 
Table 2 . PTC optical parameters.

\begin{tabular}{|c|c|}
\hline Parameters & Value \\
\hline Overall average optical error & $03 \mathrm{mrad}$ \\
\hline Mirror reflectivity $\left(\rho_{\mathrm{m}}\right)$ & 0.85 \\
\hline Glass tube transmissivity $(\tau)$ & 0.945 \\
\hline Receiver tube absorptivity $(\alpha)$ & 0.90 \\
\hline Receiver tube Emissivity $\left(\varepsilon_{\mathrm{A}}\right)$ & 0.12 \\
\hline Glass tube emissivity $\left(\varepsilon_{\mathrm{V}}\right)$ & 0.935 \\
\hline
\end{tabular}

Heat exchange occurs between the working fluid (water), the receiver tube and the glass tube. A calculation program in Engineering Equation Solver has been developed to make the necessary calculations according to the following hypotheses:

- The heat transfer fluid is incompressible;

- The ambient temperature around the studied PTC is uniform;

- The effect of the receiver tube shadow on the mirror is negligible;

- The solar flux at the receiver tube is evenly distributed;

- The glass tube is considered opaque to infrared radiation;

- The conduction exchanges in the receiver and glass tube are negligible;

- The water mass flow into receiver tube is $0.015 \mathrm{~kg} / \mathrm{s}$;

- The water inlet temperature " $\mathrm{T}_{\mathrm{i}},(\mathrm{K})$ " is $298.15 \mathrm{~K}$.

The amount of useful energy " $\mathrm{Q}_{\text {gain, }}(\mathrm{W})$ " that the working fluid acquires from the absorption tube can be estimated as follows [리, $\underline{32}]$ :

$$
\mathrm{Q}_{\text {gain }}=\mathrm{F}_{\mathrm{r}}\left[\eta_{\mathrm{op}} \mathrm{DNIA}_{\mathrm{a}}-\mathrm{U}_{\mathrm{L}} \mathrm{A}_{\mathrm{r}}\left(\mathrm{T}_{\mathrm{i}}-\mathrm{T}_{\mathrm{amb}}\right)\right]
$$

With " $\mathrm{A}_{\mathrm{a}},\left(\mathrm{m}^{2}\right)$ " is the PTC opening area, "Ar, $\left(\mathrm{m}^{2}\right)$ " is the receiver tube surface, " $\mathrm{T}_{\mathrm{amb}},(\mathrm{K})$ "is the ambient air temperature and " $\mathrm{F}_{\mathrm{r}}$ " is the heat dissipation factor.

As for the PTC optical performance, it can be expressed by [33-35]:

$$
\eta_{\mathrm{opt}}=\tau \times \alpha \times \rho_{\mathrm{m}} \times \gamma \times \mathrm{K}(\theta)
$$

With " $K(\theta)$ " shows the correction coefficient of incidence angle modifier [35, 36].

Regarding overall heat loss coefficient " $\mathrm{U}_{\mathrm{L}}$, $\left(\mathrm{W} / \mathrm{m}^{2} . \mathrm{K}\right) "$, it is given as follows $[\underline{19}, \underline{31}, \underline{32}]$ :

$$
U_{L}=\left[\frac{A_{r}}{\left(h_{w}+h_{r, c-a}\right) A_{G}}+\frac{1}{h_{r, r-a}}\right]^{-1}
$$

With " $\mathrm{A}_{\mathrm{G}},\left(\mathrm{m}^{2}\right)$ " is the glass tube area, $" \mathrm{~h}_{\mathrm{w}},\left(\mathrm{W} / \mathrm{m}^{2} \cdot \mathrm{K}\right)$ " is the wind convection coefficient, $" \mathrm{~h}_{\mathrm{r}, \mathrm{ca}},\left(\mathrm{W} / \mathrm{m}^{2} \cdot \mathrm{K}\right)$ " is the radiative exchange coefficient between the glass and the ambient air and $" h_{\mathrm{r}, \mathrm{ra}},\left(\mathrm{W} / \mathrm{m}^{2} . \mathrm{K}\right) "$ is the radiative exchange coefficient between the absorber and the glass.

Regarding working fluid temperature " $\mathrm{T}_{0},(\mathrm{~K})$ " at the absorber tube exit, it is given by $[\underline{19}, \underline{32}, \underline{37}]$ :

$$
\mathrm{T}_{\mathrm{o}}=\mathrm{T}_{\mathrm{i}}+\frac{q_{\text {gain }}}{\dot{m} \mathrm{C}_{\mathrm{p}}}
$$

As for the PTC thermal performance, it is given by:

$$
\eta_{\text {th }}=\eta_{\mathrm{opt}}-\frac{\mathrm{U}_{\mathrm{L}} \times \mathrm{A}_{\mathrm{A}, \mathrm{ext}} \times\left(\mathrm{T}_{\mathrm{Ab}}-\mathrm{T}_{\mathrm{amb}}\right)}{\mathrm{DNI} \times \mathrm{A}_{\mathrm{a}}}
$$

The thermal behavior of the studied solar reflector was attributed using EES, which was used as a programming language.

\section{Results and discussion}

As shown in Figure 3, the ejector solar air conditioning machine is a system that has three sources of heat (a hot source corresponding to the motive heat supplied to the system, a cold source corresponding to the cold production and an intermediate source that allows the connection between the hot and cold sources).

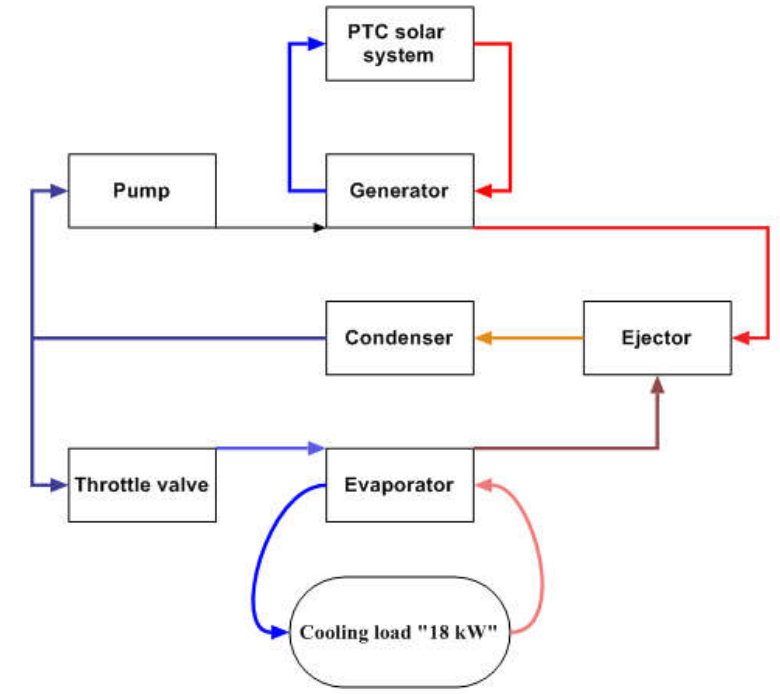

Figure 3. Solar ejector air conditioner for balance analysis

The ejector solar air conditioner is similar to the conventional compression air conditioning system except that a pump, a steam generator and an ejector replace the compressor. The beam radiation transformed by the PTC reflector to thermal energy is used to generate a high temperature and pressure steam in the generator (primary fluid) that expands in the primary nozzle of the ejector. At the outlet, the high speed primary fluid drives the secondary fluid from the evaporator. Then, the primary and secondary streams mix at constant pressure in the 
mixing chamber. A first pressure increase due to the formation of a shock wave takes place in the mixing chamber followed by a second due to compression in the Diffuser. At the diffuser outlet, the mixture condenses in the condenser, as a part of the condensate passes into the evaporator through a throttle valve to produce the cooling effect while the rest of the refrigerant returns to the generator via a circulation pump.

Regarding system thermal performance, it can be introduced as the product of the ejector air conditioning subsystem performance (COPejc) and the PTC thermal performance $\left(\eta_{\mathrm{th}}\right)$. As for the system thermal ratio, it is given by $[\underline{18}, \underline{19}, \underline{23}]$ :

$$
S T R=C O P_{e j c} \times \eta_{t h}
$$

This work aims to determine the parameters that are affected on the performance of the studied system based on the operating conditions shown in Table 3 , where the studied solar reflector is without storage tank and without auxiliary boiler. The simulation is executed under the following assumptions:

- $\quad$ R718 is considered a perfect fluid with constant thermophysical parameters and its flow is stationary;

- The kinetic energy of primary and secondary flows is negligible ;

- The internal walls of the ejector are adiabatic ;

- The outlet of the ejector is connected to the condenser.

Table 3. Operating conditions of the ejector solar air conditioner.

\begin{tabular}{|c|c|}
\hline Service operating conditions & Value $(\mathbf{K})$ \\
\hline Generator temperature $\left(\mathrm{T}_{\mathrm{b}}\right)$ & 393.15 \\
\hline Condenser temperature $\left(\mathrm{T}_{\mathrm{c}}\right)$ & 308.15 \\
\hline Evaporator temperature $\left(\mathrm{T}_{\mathrm{e}}\right)$ & 288.15 \\
\hline
\end{tabular}

On June $11^{\text {th }}, 2018$ in Bouzaréah, Sun rises at 05:28 and sets about 14 hours and 39 minutes later (at 20:06), where the solar noon is at 12:47. As for the average air temperature, it varies from 289.15 to 301.15 $\mathrm{K}$, where the average hourly wind speed varies with a daily average of $3.61 \mathrm{~m} / \mathrm{s}$. Figure 4 illustrates the changes in beam radiation on June $11^{\text {th }}, 2018$ at Bouzaréah, Algeria.

As shown in Figure 4, the maximum value of beam radiation is $1020.13 \mathrm{~W} / \mathrm{m}^{2}$ at $12: 02$, where its minimum value is $53.30 \mathrm{~W} / \mathrm{m}^{2}$ just before sunset and the mean beam radiation is $853 \mathrm{~W} / \mathrm{m}^{2}$. As it is noticed, the beam radiation quantity for the studied day is very considered, and it can be used for many uses such as air conditioning and seawater desalination in the region.

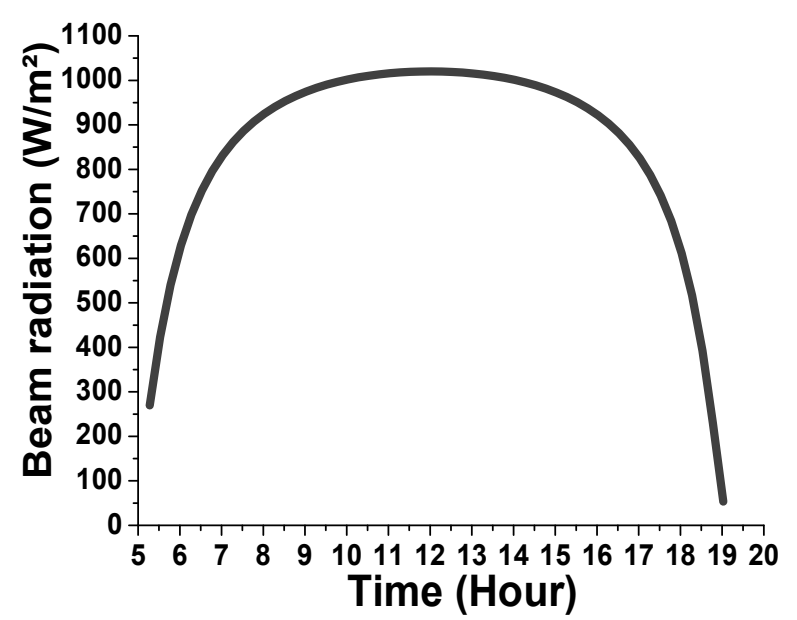

Figure 4. Beam radiation assessment.

Figure 5 shows the change in temperature of the working fluid " $\mathrm{T}_{\mathrm{HTF}},(\mathrm{K})$ ", the receiver tube " $\mathrm{T}_{\mathrm{Ab}},(\mathrm{K})$ " and the surrounding glass tube " $\mathrm{T}_{\mathrm{G}},(\mathrm{K})$ ". From Figure 5 , it observed that the mean working fluid temperature is $431.15 \mathrm{~K}$, i.e., the water has changed its nature from the liquid state to the vapor's intense heat in order to drive the ejector air conditioning subsystem by pumping this acquired heat to the generator, where it is noticed that the water is in a steam state from 08:00 until 17:00, meaning that the studied conditioner will work for nine hours continuously with solar energy without any interruption.

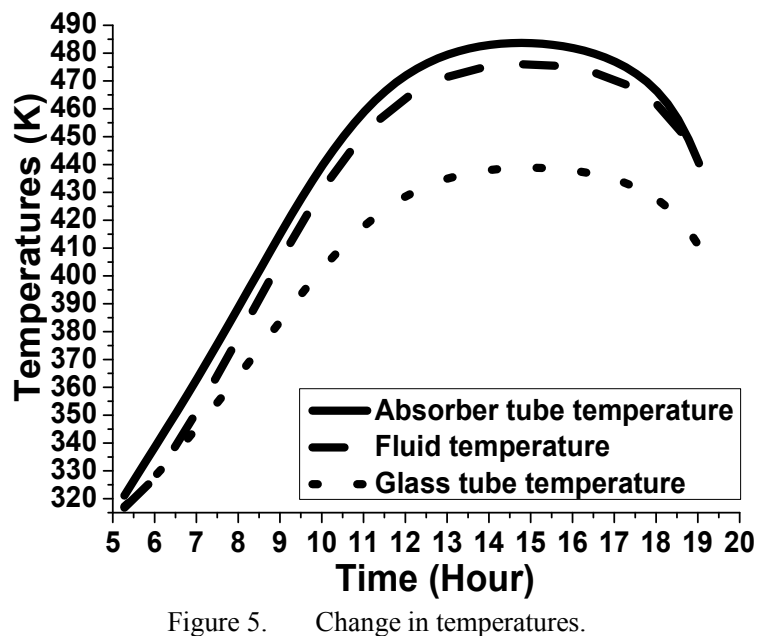

As for the mean values of receiver tube and glass tube temperatures, they are $439.12 \mathrm{~K}$ and $404.39 \mathrm{~K}$, respectively. In addition, it is observed from Figure 5 that the receiver tube and glass tube temperatures are high, however the values of the heat loss coefficient " $U_{L}$, $\left(\mathrm{W} / \mathrm{m}^{2} . \mathrm{K}\right)$ " are acceptable as shown in Figure 6, and this is due to the emptying of the space between them from the air. 


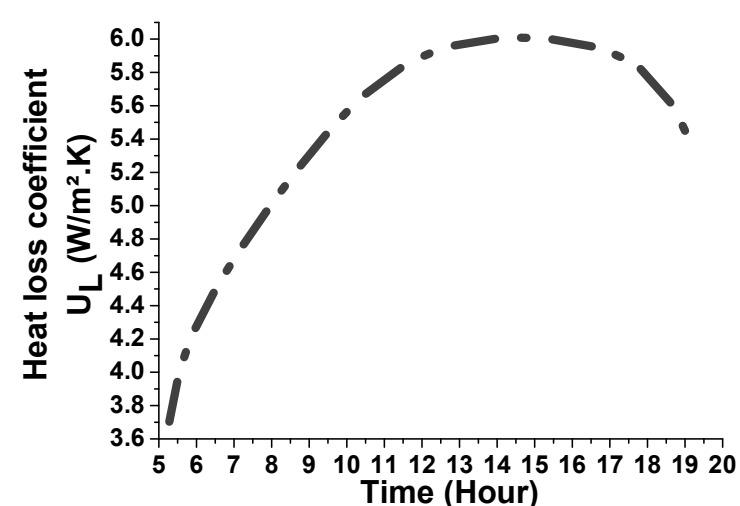

Figure 6. Assessment of overall heat loss coefficient vs. time.

Regarding heat loss coefficient, it varies from 3.70 to $6 \mathrm{~W} / \mathrm{m}^{2} . \mathrm{K}$ ant its mean value is $5.50 \mathrm{~W} / \mathrm{m}^{2} . \mathrm{K}$.

Unlike conventional compression air conditioning systems, solar ejector air conditioners do not have a mechanical compressor, but they have an ejection thermal system (a solar thermal generator, a pump and a steam ejector). By numerical simulation, the ejector dimensions that correspond to the operating conditions of the air-conditioning system shown in Table 3 have been obtained. Table 4 shows the dimensions of primary nozzle throat diameter $\left(D_{t}\right)$ and constant area section diameter $\left(D_{m}\right)$ which is characterized by the ejector under critical conditions $\left(\mathrm{P}_{4} \leq \mathrm{P}_{\mathrm{c}}\right.$, where $\left.\mathrm{P}_{\mathrm{c}}=5627 \mathrm{~Pa}\right)$ with the previous operating conditions and with a load cold equal to $18 \mathrm{~kW}$.

Table 4. Dimensions of $\left(D_{t}\right)$ and $\left(D_{m}\right)$ under critical conditions

\begin{tabular}{|c|c|c|}
\hline $\begin{array}{c}\text { Ejector critical } \\
\text { condition }\end{array}$ & $\begin{array}{c}\text { Primary nozzle throat } \\
\text { diameter }\left(\mathbf{D}_{\mathbf{t}}\right)\end{array}$ & $0.004009 \mathrm{~m}$ \\
\cline { 2 - 3 }$\left(\mathbf{P}_{\mathbf{4}} \leq \mathbf{P}_{\mathbf{c}}=\mathbf{5 6 2 7} \mathbf{P a}\right)$ & $\begin{array}{c}\text { Constant area section } \\
\text { diameter }\left(\mathbf{D}_{\mathbf{m}}\right)\end{array}$ & $0.04214 \mathrm{~m}$ \\
\hline
\end{tabular}

Table 5 illustrates the drive ratio $(\omega)$ and ejector performance values of the studied air conditioning subsystem.

Table 5. The drive ratio $(\omega)$ and ejector performance $\left(\mathrm{COP}_{\mathrm{EIC}}\right)$ of the studied ejector subsystem.

\begin{tabular}{|c|c|c|}
\hline $\begin{array}{c}\text { Ejector critical condition } \\
\left(\mathbf{P}_{\mathbf{4}} \leq \mathbf{P}_{\mathbf{c}}=\mathbf{5 6 2 7} \mathbf{P a}\right)\end{array}$ & $\omega$ & 0.8376 \\
\cline { 2 - 3 } & $\mathrm{COP}_{\mathrm{ejc}}$ & 0.6235 \\
\hline
\end{tabular}

Regarding PTC optical performance, PTC thermal efficiency and system thermal ratio, they are shown in Figure 7.

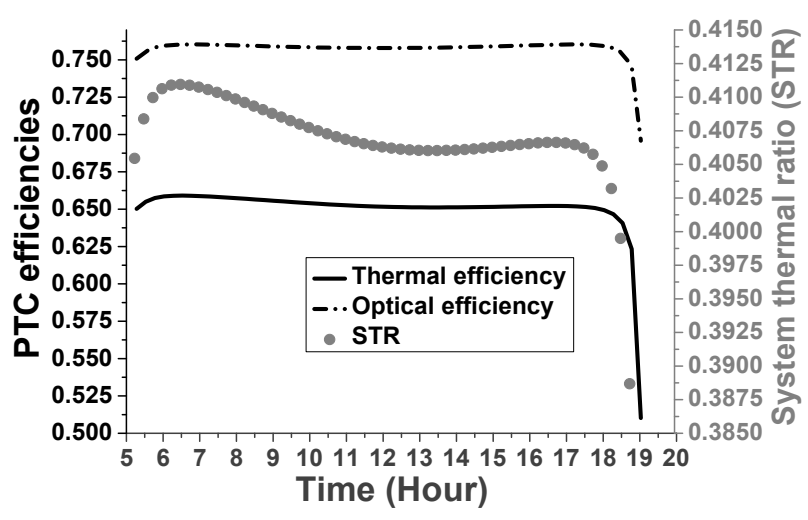

Figure 7. Assessment of the system performances.

As for the PTC optical performance, its mean value is $75.74 \%$, while the mean value of PTC thermal efficiency is $65.01 \%$. Concerning thermal system ratio, it varies from 0.39 to 0.411 . The solar ejector air conditioner is a tri-thermal machine that allows using three temperature levels in order to produce cold from heat only. It is noticeable that the overall performance of the system (STR) is low, however this system is effective and sufficient for adapting, as it provides a cooling load of $18 \mathrm{~kW}$ for a period of nine hours a day without consuming any electricity except a very small amount to operate the pump. Generally, the system thermal ratio varies automatically according to the temperatures $\left(T_{e}\right)$, $\left(\mathrm{T}_{\mathrm{c}}\right)$ and $\left(\mathrm{T}_{\mathrm{b}}\right)$ of the ejector air conditioning subsystem, and is affected by the change in PTC thermal efficiency.

\section{Conclusion}

The ejector solar air conditioner uses the ejector as a static compressor, which the ejector uses the primary fluid vapor as driving energy. The ejector solar air conditioner has four main elements as follow generator, ejector, condenser and the evaporator. In addition, it consists of two loops; one is the driving loop and the other the cooling loop.

This work has allowed acquiring very important knowledge about R718 ejector solar air conditioners. Bouzaréah was chosen as the region to conduct this numerical study on June $11^{\text {th }}$, 2018. Regarding performance of the studied air conditioning subsystem $\left(\mathrm{COP}_{\mathrm{ejc}}\right)$ is 0.6235 , as it is very sensitive to changes in condenser temperature $\left(\mathrm{T}_{\mathrm{c}}\right)$, so to improve the performance of the machine it is necessary to increase the temperature of hot and cold sources $\left(\mathrm{T}_{\mathrm{b}}\right.$ and $\left.\mathrm{T}_{\mathrm{e}}\right)$. As for the PTC solar reflector subsystem, its mean optical performance is $75.74 \%$ and its mean thermal performance is $65.01 \%$. Regarding the system thermal ratio, its mean value is 0.407 , knowing that the cooling load of the studied machine is $18 \mathrm{~kW}$. 
Finally, this type of solar air conditioner can be an ideal solution for providing luxury and air conditioning in residential complexes, institutional buildings, and at the living bases of workers in the hydrocarbon sector in southern Algeria. This technology is low cost and does not contain any negative effects on the environment, as it contributes to the development of sustainable technology.

As prospective, the research team in the future will manufacture a prototype for this R718 ejector solar air, then conduct practical experiments on it in order to track its thermodynamic behavior and then improve its performance.

\section{REFERENCES}

[1] M. Ghodbane, B. Boumeddane, and N. Said, "A linear Fresnel reflector as a solar system for heating water: theoretical and experimental study," Case Studies in Thermal Engineering, vol. 8, no. C, 2016; pp. 176-186,

[2] M. Ghodbane and B. Boumeddane, "Estimating solar radiation according to semi empirical approach of PERRIN DE BRICHAMBAUT: application on several areas with different climate in Algeria," International Journal of Energetica, vol. 1, no. 1, 2016, pp. 20-29.

[3] M. Ghodbane, B. Boumeddane, and N. Said, "Design and experimental study of a solar system for heating water utilizing a linear Fresnel reflector," Journal of Fundamental and Applied Sciences, vol. 8, no. 3, 2016, pp. 804-825,

[4] M. Ghodbane, B. Boumeddane, Z. Said, and E. Bellos, "A numerical simulation of a linear Fresnel solar reflector directed to produce steam for the power plant," Journal of Cleaner Production, vol. 231, 2019, pp. 494-508.

[5] E. Bellos and C. Tzivanidis, "Optimum design of a solar ejector refrigeration system for various operating scenarios," Energy Conversion and Management, vol. 154, 2017, pp. 11-24.

[6] E. Bellos and C. Tzivanidis, "Parametric analysis and optimization of a cooling system with ejectorabsorption chiller powered by solar parabolic trough collectors," Energy Conversion and Management, vol. 168, 2018, pp. 329-342.

[7] E. Bellos, I. C. Theodosiou, L. Vellios, and C. Tzivanidis, "Investigation of a novel solar-driven refrigeration system with ejector," Thermal Science and Engineering Progress, vol. 8, 2018, pp. 284-295.

[8] Z. Zhang, X. Feng, D. Tian, J. Yang, and L. Chang, "Progress in ejector-expansion vapor compression refrigeration and heat pump systems," Energy Conversion and Management, vol. 207, 2020, pp. 112529.

[9] V. V. Nguyen, S. Varga, J. Soares, V. Dvorak, and A. C. Oliveira, "Applying a variable geometry ejector in a solar ejector refrigeration system," International Journal of Refrigeration, 2020.

[10] Y. Han et al., "Characterization of Choking Flow Behaviors inside Steam Ejectors Based on the Ejector Refrigeration System," International Journal of Refrigeration, 2020.
[11] M. Habibi, F. Aligolzadeh, and A. Hakkaki-Fard, "A techno-economic analysis of geothermal ejector cooling system," Energy, vol. 193, 2020, pp. 116760.

[12] F. Foroozesh, A. B. Khoshnevis, and E. Lakzian, "Improvement of the wet steam ejector performance in a refrigeration cycle via changing the ejector geometry by a novel EEC (Entropy generation, Entrainment ratio, and Coefficient of performance) method," International Journal of Refrigeration, vol. 110, 2020, pp. 248-261.

[13] H. S. Cao and H. J. M. ter Brake, "Progress and challenges in utilization of ejectors for cryogenic cooling," Applied Thermal Engineering, Vol. 167, 2020, pp. 114783.

[14] M. Bencharif, H. Nesreddine, S. C. Perez, S. Poncet, and $\mathrm{S}$. Zid, "The benefit of droplet injection on the performance of an ejector refrigeration cycle working with R245fa", International Journal of Refrigeration, 2020.

[15] A. Mwesigye, A. Kiamari, and S. B. Dworkin, "Energetic Optimization and Exergetic Performance Investigation of an Ejector System Using HCFO$1233 z d(E)$ as a Refrigerant", International Journal of Refrigeration, 2019.

[16] G. Chen, V. Ierin, O. Volovyk, and K. Shestopalov, "Thermodynamic analysis of ejector cooling cycles with heat-driven feed pumping devices", Energy, vol. 186, 2019, pp. 115892.

[17] S. Varga, P. M. S. Lebre, and A. C. Oliveira, "CFD study of a variable area ratio ejector using R600a and R152a refrigerants. International journal of refrigeration vol. 36, 2013, pp. 157-165.

[18] W. Pridasawas and P. Lundqvist, "A year-round dynamic simulation of a solar-driven ejector refrigeration system with iso-butane as a refrigerant," International Journal of Refrigeration, vol. 30, 2007, pp. $840-850$,

[19] M. Ghodbane and B. Boumeddane, "Numerical simulation of a solar-driven ejector refrigeration cycle coupled to a parabolic trough concentrator " International Journal of Chemical and Petroleum Sciences, Vol. 5, No. 1, 2016, pp. 1-12.

[20] M. Ghodbane, "Étude et optimisation des performances d'une machine de climatisation a éjecteur reliée à un concentrateur solaire " Doctorat en système énergétiques et thermiques, Département de Mécanique Université Saad Dahleb de Blida 1 2017.

[21] M. Ghodbane, B. Boumeddane, S. Largot, and H. Berkane, "Modélisation d'un cycle de réfrigération solaire à éjecteur couplée à un concentrateur cylindro-parabolique," in International Conférence en Clean Cooling Technologies in the ME NA Regions (ICT3_MENA'2015) Bou Smail, W. Tipaza, 5-6 2015 .

[22] M. Ghodbane and B. Boumeddane, "Physical description of an isentropic flow in a Laval nozzle", Revue des Energies Renouvelables, vol. 19, no. 1, pp. 41-47, 2016.

[23] W. Pridasawas and P. Lundqvist, "An exergy analysis of a solar-driven ejector refrigeration system," Solar Energy, vol. 76, pp. 369-379, 2004.

[24] M. Ghodbane, Z. Said, A. A. Hachicha, and B. Boumeddane, "Performance assessment of linear Fresnel solar reflector using MWCNTs/DW nanofluids," Renewable Energy, , 2019. 
[25] Z. Said, M. Ghodbane, A. A. Hachicha, and B. Boumeddane, "Optical performance assessment of a small experimental prototype of linear Fresnel reflector", Case Studies in Thermal Engineering, , 2019.

[26] M. Ghodbane, E. Bellos, Z. Said, B. Boumeddane, A. K. Hussein, and L. Kolsi, "Evaluating energy efficiency and economic effect of heat transfer in copper tube for small solar linear Fresnel reflector", Journal of Thermal Analysis and Calorimetry, 2020.

[27] E. Bellos, C. Tzivanidis, and A. Papadopoulos, "Enhancing the performance of a linear Fresnel reflector using nanofluids and internal finned absorber," Journal of Thermal Analysis and Calorimetry, vol. 135, no. 1, 2019, pp. 237-255.

[28] A. Fernandez-Garcia, E. Zarza, L. Valenzuela, and M. Perez, "Parabolic-trough solar collectors and their applications," Renewable and Sustainable Energy Reviews, vol. 14, 2010, pp. 1695-1721.

[29] E. Bellos and C. Tzivanidis, "Alternative designs of parabolic trough solar collectors," Progress in Energy and Combustion Science, vol. 71, 2019, pp. 81-117.

[30] M. Ghodbane and B. Boumeddane, "A parabolic trough solar collector as a solar system for heating water: a study based on numerical simulation," International Journal of Energetica, vol. 2, no. 2, 2017, pp. 29-37.

[31] S. A. Kalogirou, Solar Energy Engineering : Processes and Systems, 1st ed. Academic Press, 2009.

[32] M. Ghodbane, B. Boumeddane, and S. Largot, "Simulation Numérique d'un Concentrateur Cylindro-Parabolique en El Oued, Algérie," International Journal of Scientific Research \& Engineering Technology (IJSET), vol. 3, no. 2, 2015, pp. 68-74.

[33] K. F. Yogi D.G, Kreider J.F, " Off-Normal Incidence Effects," in Principles of solar engineering, T. Francis., Ed. 2nd Edition ed., 1999, p. 139.

[34] M. Ghodbane and B. Boumeddane, "A numerical analysis of the energy behavior of a parabolic trough concentrator," Journal of Fundamental and Applied Sciences, vol. 8, no. 3, 2016, pp. 671-691.

[35] M. Ghodbane and B. Boumeddane, "Engineering design and optical investigation of a concentrating collector: Case study of a parabolic trough concentrator " Journal of Fundamental and Applied Sciences vol. 10, no. 2, 2018, pp. 148-171.

[36] E. Bellos, "Progress in the design and the applications of Linear Fresnel Reflectors - A critical review," Thermal Science and Engineering Progress, 2019.

[37] M. Li and L. L. Wang, "Investigation of evacuated tube heated by solar trough concentrating system. " Energy Conversion and Management, vol. 47, 2006, pp. 3591-3601. 